\title{
EPIGENETIC REGULATION OF MUSCLE DEVELOPMENT
}

\section{${ }^{1,2,3}$ Esther Barreiro and ${ }^{4}$ Shahragim Tajbakhsh}

${ }^{1}$ Respiratory Medicine Department, Muscle Wasting and Cachexia in Chronic Respiratory

Diseases and Lung Cancer Research Group, Institute of Medical Research of Hospital del Mar (IMIM)-Hospital del Mar, Parc de Salut Mar, Barcelona Biomedical Research Park (PRBB), Barcelona, Spain.

${ }^{2}$ Department of Health Sciences (CEXS), Universitat Pompeu Fabra, Barcelona, Spain. ${ }^{3}$ Centro de Investigación en Red de Enfermedades Respiratorias (CIBERES), Instituto de Salud Carlos III (ISCIII), Barcelona, Spain.

${ }^{4}$ Institut Pasteur, Stem Cells \& Development, CNRS URA 3738, Dept. of Developmental \& Stem Cell Biology, 25 rue du Dr. Roux, 75724 Paris Cedex 15, France

Corresponding author: Dr. Esther Barreiro

Running title: Epigenetics in myogenesis

Word count: 2,152 


\section{ABSTRACT}

In eukaryote cells, chromatin appears in several forms and is composed of genomic DNA, protein and RNA. The protein content of chromatin is composed primarily of core histones that are packaged into nucleosomes resulting in the condensation of the DNA. Several epigenetic mechanisms regulate the stability of the nucleosomes and the protein-protein interactions that modify the transcriptional activity of the DNA. Interestingly, epigenetic control of gene expression has recently emerged as a relevant mechanism involved in the regulation of many different biological processes including that of muscle development, muscle mass maintenance, function, and phenotype in health and disease. Recent investigations have shed light into the epigenetic control of biological mechanisms that are key regulators of embryonic muscle development and postnatal myogenesis. In the present review article, we provide a summary of the contents discussed in session 08, titled "Epigenetics of muscle regeneration", during the course of the $45^{\text {th }}$ European Muscle Conference, which was celebrated in Montpellier (France) in September 2016. The main theme of that session was to highlight the most recent progress on the role of epigenetics in the regulation of muscle development and regeneration. The current mini-review has been divided into two major sections. On the one hand, a brief introduction on the topic of myogenesis is offered for the nonspecialized reader. On the other, a brief overview of the most relevant epigenetic players that have been shown to control muscle development and regeneration is given.

\section{Word count: 238}

KEY WORDS: epigenetics; skeletal muscles; embryonic muscle development; muscle repair and postnatal myogenesis 


\section{INTRODUCTION}

Packaging of DNA into a compact structure, to control gene transcription, and to protect DNA from damage are among the most relevant functions of chromatin in eukaryotic cells. Chromatin that is structurally loose allows gene transcription (euchromatin), whereas highly condensed chromatin (heterochromatin) is generally associated with repression of gene transcription and genome stability. Specifically, chromatin is composed of nucleosomes that are comprised of two copies of each of $\mathrm{H} 2 \mathrm{~A}, \mathrm{H} 2 \mathrm{~B}, \mathrm{H} 3$, and $\mathrm{H} 4$, and these structures are compacted into chromatin by linker histones such as H1. Epigenetic control of cell behaviour, defined as the process whereby gene expression is regulated by heritable mechanisms that do not affect DNA sequence, can affect cell growth and differentiation and impact on the pathophysiology of chronic and acute diseases. Several epigenetic mechanisms regulate the stability of the nucleosomes and the protein-protein interactions that modify the transcriptional activity of the DNA (Baar, 2010). A few examples of epigenetic modifications include: 1) non-coding RNAs including microRNAs, 2) histone acetylation and deacetylation, 3) histone methylation, and 4) DNA methylation. Interestingly, epigenetic control of gene expression has recently emerged as a relevant mechanism involved in the regulation of many different biological processes including that of muscle mass, function, and phenotype in health and disease (Donaldson et al, 2013;Lewis et al, 2012;Puig-Vilanova et al, 2014a;PuigVilanova et al, 2014b;Puig-Vilanova et al, 2015). In the present review we summarize the contents discussed in the "Epigenetics of muscle regeneration" session at the $45^{\text {th }}$ European Muscle Conference. The main theme of that session was to highlight the most recent progress on the role of epigenetics in the regulation of the process of muscle regeneration. As such, the current mini-review has been divided into two major sections: i) a brief introduction on the topic of muscle development and postnatal 
myogenesis; and ii) the most relevant epigenetic players that control muscle development and regeneration.

\section{MUSCLE DEVELOPMENT}

During embryonic myogenesis, paraxial mesoderm derived cells generate the first primary muscle fibers of the body that act as a scaffold for the formation of secondary fibers. The latter appear during foetal development and they continue to grow by nuclear accretion until perinatal stages (Comai and Tajbakhsh, 2014). A reservoir of myogenic cells is subsequently allocated during the perinatal period and it will give rise to the satellite (stem) cells. The privileged position of these cells on the surface of the myofiber, beneath the basal lamina, enables them to respond to mechanical, structural, and functional stimuli of skeletal muscle fibers. During the early juvenile growth phase, satellite cells proliferate and add nuclei to the growing myofibers; subsequently, proliferation declines gradually as myofibers increase in diameter (Moss and Leblond, 1971; White et al, 2010). In adult muscles, satellite cells remain quiescent until muscle injury triggers their activation (Snow, 1978; Yablonka-Reuveni, 1995). Despite certain differences such as the lack of a primary myogenesis wave (Tajbakhsh, 2009), prenatal and postnatal myogenesis share some molecular and functional similarities including the sequential appearance of transcription factors from an upstream state (ex. Pax7, Myf5) to a committed and differentiated state (ex. MyoD, Myogenin) (Parker et al, 2003). Small injuries, such as those promoted by daily life activities, lead to minimal proliferation, whereas major lesions induce longer proliferation periods before differentiation may take place (Yablonka-Reuveni, 2011). Signals from the muscle niche, microvasculture, local inflammation (Yablonka-Reuveni, 2011) and systemic factors activate satellite cells (Carlson et al, 2009;Conboy et al, 2005). 
In response to muscle injury, satellite cells contribute to repair of damaged fibers while new myofibers are also formed following a program of cell division and fusion of myoblasts (Yablonka-Reuveni et al, 2008). A number of regulatory factors control satellite cell behaviour from quiescence, entry into proliferation, maintenance of the cell cycle, differentiation, and subsequent self-renewal following return to homeostasis (Yablonka-Reuveni et al, 2008) (Collins et al, 2005;Sacco et al, 2008). It has been estimated that during early postnatal growth, satellite cells represent $30 \%$ of the nuclei, while they only constitute $2 \%-7 \%$ of nuclei in healthy adult skeletal muscles (Halevy et al, 2004;Hawke and Garry, 2001). The numbers of satellite cells were also reported to decline with age in healthy elderly subjects (Collins et al, 2007; Shefer et al, 2006).

The basic helix-loop-helix transcription factor MyoD plays a key role in muscle determination and differentiation, and it is one of the earliest markers of myogenic commitment. Notably, seminal experiments demonstrated that MyoD can transform a variety of cell types, including fibroblasts, into myoblasts that will subsequently fuse to form myotubes (Davis et al, 1987). In quiescent satellite cells that are characterized by the expression of Pax7, MyoD protein is generally not detectable. Following their activation, MyoD transcription and protein levels increase dramatically (Comai and Tajbakhsh, 2014). As a transcription factor, MyoD binds to enhancers and promoters to regulate myogenesis, and it was shown to activate muscle genes in a variety of differentiated cell lines from several species (chicken, human, and rat) (Weintraub et al, 1989). Myf5 and Mrf4 also act as determination genes, whereas Myogenin is a differentiation factor - and each of these factors that belong to the MyoD family have unique and overlapping properties as well as expression patterns during embryogenesis (Comai and Tajbakhsh, 2014). 
Early striated muscle development arising from somites in the trunk is the result of the action of the paired-homeobox transcription factors $\operatorname{Pax3}$ and $\operatorname{Pax} 7$ genes. Importantly, genetic ablation of the Pax3 lineage was embryonically lethal and prevented the emergence of Pax7-positive cells, while ablation of Pax7-expressing cells resulted in the appearance of smaller muscles with fewer myofibers in the limbs at birth (Hutcheson et al, 2009; Seale et al, 2000). Pax3 is a key factor in the regulation of myogenesis for skeletal muscles in the trunk and limbs where some downstream targets include MyoD and the tyrosine kinase receptor c-met. Although its expression is not restricted to skeletal muscle, $\operatorname{Pax} 3$ is expressed well before the onset of myogenesis, in presomitic mesoderm, and subsequently its expression is restricted to the epithelial dermomyotome of the somite that gives rise to multiple cell types including all of the myogenic cells of the trunk and limbs. Notably, Pax3 is not expressed in head derived muscle progenitors. In this case, Tbxl and Pitx2, among other transcription factors, play critical roles in establishing myogenesis from cranial mesoderm (Comai and Tajbakhsh, 2014).

\section{EPIGENETIC REGULATION OF MYOGENESIS/ MUSCLE DEVELOPMENT}

Epigenetic events regulate the quiescent and proliferation states of muscle satellite cells and their progeny. In this context, DNA methylation is a major repressive mechanism of muscle satellite cell differentiation (Palacios and Puri, 2006;Bigot et al, 2015), whereas demethylation along with $M y o D$ and Myogenin are required for the initiation of the differentiation program (Palacios and Puri, 2006). Mechanisms that act on chromatin-associated histones are also involved in the control of muscle satellite cell quiescence and proliferation. Histone acetylation is a transient, enzymatically controlled biochemical process, and the most common posttranslational modification of histone 
proteins. The acetyl group from acetyl-CoA is transferred to a lysine residue, thus converting its basic side chain into a neutral residue thereby resulting in an open chromatin (euchromatin) structure that is transcriptionally active. Deacetylation reverses this process, leading to a closed chromatin structure (heterochromatin) that is generally transcriptionally repressed. Histone deacetylases (HDACs) are enzymes that remove acetyl groups from lysine residues of histone proteins, allowing the histones to condense DNA. HDACs also interact with chromatin through association with other histonemodifying proteins and transcription factors, and they also remove lysine residues from non-histone proteins. Importantly, in proliferating myoblasts, HDAC1-5 and Sirtuins maintain transcription factors in a deacetylated state, particularly when differentiationpromoting signals are absent. Other epigenetic mechanisms such as the expression of specific histone isoforms or the replacement of canonical histones with histone variants can regulate muscle satellite cell quiescence and proliferation (Perdiguero et al, 2009).

Epigenetic mechanisms also control the gene expression program during muscle differentiation. In this regard, genes that are actively transcribing are marked by H3K4me3, whereas those ready to be transcribed can be marked by H3K4me2 (Guenther et al, 2007). As such, Pax7 was shown to bind to $\mathrm{H} 3 \mathrm{~K} 4 \mathrm{me} 2$ regulatory elements in target genes such as Myf5 in satellite cells (Kuang et al, 2007;McKinnell et al, 2008). Interestingly, this binding leads to the recruitment of TRxG histone methyltransferase complex, which in turn will result in elevated $\mathrm{H} 3 \mathrm{~K} 4$ trimethlyation on the transcription start site (Kuang et al, 2007;McKinnell et al, 2008). Finally, inactivation of HDACs and Sirtuins together with the concomitant activation of HTAs will allow the activation of transcription factors and nucleosomes for the muscle differentiation program to proceed. 
The non-coding microRNAs also play an important role in the control of muscle development. Interestingly, miRNAs are non-coding single-stranded RNA molecules (18-24 nucleotides) that function in the post-transcriptional regulation of gene expression. They exert their action via base-pairing with complementary sequences of mRNA molecules which result in gene silencing via translational repression or target degradation. Importantly, miRNAs may have different mRNA targets, and a given mRNA may also be targeted by multiple miRNAs in a similar fashion. It is well known that miRNAs regulate many cellular processes and have a role in disease pathogenesis, and muscle development. Although microRNAs regulate a wide variety of biological processes in different tissues, tissue-specificity also exists for certain microRNAs. For example, miR-1, miR-133, and miR-206 have been shown to be abundantly expressed in skeletal muscles and they are defined as muscle-specific microRNAs (myomiRs). Several steps of muscle development are tightly regulated by these muscle-specific microRNAs. Despite the potential limitations of the findings reported so far, as a result of the in vitro and/or the use of genetically modified mice, a brief overview on how microRNAs can regulate myogenesis is provided below.

Perinatal lethality, reduced muscle mass, and abnormal myofiber structure has been reported following inactivation of Dicer, which leads to the accumulation of unprocessed pre-miRNAs (O'Rourke et al, 2007) thereby pointing to a critical role for myomiRs in skeletal muscle development. The molecules miR-1 and miR-133, which are localized within the same chromosomal locus and are co-transcribed, become two independent mature miRNAs with distinct biological functions in the regulation of skeletal muscle proliferation and differentiation. Interestingly, miR-133 stimulates myoblast proliferation by repressing the serum response factor, and inhibits myotube formation, whereas miR-1 promotes muscle cell differentiation as a result of targeting 
HDAC4 (Chen et al, 2006). Similarly to the action of miR-1, miR-206 was reported to promote myotube formation by targeting DNA polymerase alpha (p180 subunit), leading to the inhibition of DNA synthesis and cell cycle withdrawal, as well as to terminal cell differentiation (Deato et al, 2008; Nakajima et al, 2006). However, a recent report showed that deletion of miR206/133b resulted in no major defects in developmental and adult myogenesis, or during muscle regeneration (Boettger et al, 2014). The authors proposed that functional compensation by miR1/133a might explain this surprising lack of a phenotype. In others studies, miR-1 was suggested to target the insulin-like growth factor-1 (IGF-1) pathway, while inducing a feedback loop between miR-1 expression and the IGF-1 signal transduction cascade (Elia et al, 2009). Interestingly, downregulation of connexin 43-dependent gap junctional communication by miR-1 and miR-206 also appears to regulate innervation of muscle fibers (Anderson et al, 2006).

Importantly, other microRNAs ubiquitously expressed in tissues may also play a role in skeletal muscle development. In this context, myoblast differentiation through the downregulation of the paired-box protein Pax 7 was reported to be mediated by miR206 and miR-486 (Dey et al, 2011). Expression of these two microRNAs favors differentiation in myoblasts, whereas inhibition of their expression results in maintenance of Pax7 activity, which delayed differentiation. In embryonic myotomes, satellite cells, and adult muscle fibers, miR-27 (targets Pax3) is also expressed (Crist et al, 2009). Additionally, $M y o D$ was reported to be induced by the action of miR-181, which targets the repressor of myoblast terminal differentiation Hox-A11 (Naguibneva et al, 2006). The action of miR-29 can favor muscle development through the feedback inhibition of transcriptional repressors such as Yin Yang (YY)1 (Wang et al, 2008). Notably, loss of miR-29 was also shown to induce the transdifferentiation of myoblasts 
into myofibroblasts, and transforming growth factor (TGF)-beta signaling negatively regulated its expression (Wang et al, 2012). Indeed, miR-29 expression levels decreased in dystrophic muscles from $m d x$ mice (an experimental model of Duchene muscular dystrophy) in the same report (Wang et al, 2012). Remarkably, muscle-specific microRNAs were reported to be regulated by the action of muscle-specific transcription factors such as MyoD, Myogenin, myocyte-enhancing factor (MEF)2, and the serum response factor (Rao et al, 2006;Zhao et al, 2005). Finally, given the wide number of transcriptional targets for miRNAs, more studies are necessary before designing therapeutic strategies in patients with muscle diseases.

\section{CONCLUDING REMARKS}

Epigenetics play a paramount role in the regulation of prenatal and postnatal myogenesis. Future studies will shed light into additional mechanisms that may help understand the process of muscle development and repair following injury. Potential therapeutic strategies will likely emerge once we develop a better understanding of the biological events that underlie myogenesis and muscle repair. 
Literature Cited

Anderson C, Catoe H, Werner R (2006). MIR-206 regulates connexin43 expression during skeletal muscle development. Nucleic Acids Res 34:5863-5871.

Baar K (2010). Epigenetic control of skeletal muscle fibre type. Acta Physiol (Oxf) 199:477487.

Bigot A, Duddy WJ, Ouandaogo ZG, Negroni E, Mariot V, Ghimbovschi S, Harmon B, Wielgosik A, Loiseau C, Devaney J, Dumonceaux J, Butler-Browne G, Mouly V, Duguez S (2015). Age-Associated Methylation Suppresses SPRY1, Leading to a Failure of Re-quiescence and Loss of the Reserve Stem Cell Pool in Elderly Muscle. Cell Rep 13:1172-1182.

Boettger T, Wust S, Nolte H, Braun T (2014). The miR-206/133b cluster is dispensable for development, survival and regeneration of skeletal muscle. Skelet Muscle 4:23.

Carlson ME, Conboy MJ, Hsu M, Barchas L, Jeong J, Agrawal A, Mikels AJ, Agrawal S, Schaffer DV, Conboy IM (2009). Relative roles of TGF-beta1 and Wnt in the systemic regulation and aging of satellite cell responses. Aging Cell 8:676-689.

Chen JF, Mandel EM, Thomson JM, Wu Q, Callis TE, Hammond SM, Conlon FL, Wang DZ (2006). The role of microRNA-1 and microRNA-133 in skeletal muscle proliferation and differentiation. Nat Genet 38:228-233.

Collins CA, Olsen I, Zammit PS, Heslop L, Petrie A, Partridge TA, Morgan JE (2005). Stem cell function, self-renewal, and behavioral heterogeneity of cells from the adult muscle satellite cell niche. Cell 122:289-301.

Collins CA, Zammit PS, Ruiz AP, Morgan JE, Partridge TA (2007). A population of myogenic stem cells that survives skeletal muscle aging. Stem Cells 25:885-894.

Comai G, Tajbakhsh S (2014). Molecular and cellular regulation of skeletal myogenesis. Curr Top Dev Biol 110:1-73.

Conboy IM, Conboy MJ, Wagers AJ, Girma ER, Weissman IL, Rando TA (2005). Rejuvenation of aged progenitor cells by exposure to a young systemic environment. Nature 433:760-764.

Crist CG, Montarras D, Pallafacchina G, Rocancourt D, Cumano A, Conway SJ, Buckingham M (2009). Muscle stem cell behavior is modified by microRNA-27 regulation of Pax3 expression. Proc Natl Acad Sci U S A 106:13383-13387.

Davis RL, Weintraub H, Lassar AB (1987). Expression of a single transfected cDNA converts fibroblasts to myoblasts. Cell 51:987-1000.

Deato MD, Marr MT, Sottero T, Inouye C, Hu P, Tjian R (2008). MyoD targets TAF3/TRF3 to activate myogenin transcription. Mol Cell 32:96-105.

Dey BK, Gagan J, Dutta A (2011). miR-206 and -486 induce myoblast differentiation by downregulating Pax7. Mol Cell Biol 31:203-214.

Donaldson A, Natanek SA, Lewis A, Man WD, Hopkinson NS, Polkey MI, Kemp PR (2013). Increased skeletal muscle-specific microRNA in the blood of patients with COPD. Thorax 68:1140-1149. 
Elia L, Contu R, Quintavalle M, Varrone F, Chimenti C, Russo MA, Cimino V, De ML, Frustaci A, Catalucci D, Condorelli G (2009). Reciprocal regulation of microRNA-1 and insulin-like growth factor-1 signal transduction cascade in cardiac and skeletal muscle in physiological and pathological conditions. Circulation 120:2377-2385.

Guenther MG, Levine SS, Boyer LA, Jaenisch R, Young RA (2007). A chromatin landmark and transcription initiation at most promoters in human cells. Cell 130:77-88.

Halevy O, Piestun Y, Allouh MZ, Rosser BW, Rinkevich Y, Reshef R, Rozenboim I, Wleklinski-Lee M, Yablonka-Reuveni Z (2004). Pattern of Pax7 expression during myogenesis in the posthatch chicken establishes a model for satellite cell differentiation and renewal. Dev Dyn 231:489-502.

Hawke TJ, Garry DJ (2001). Myogenic satellite cells: physiology to molecular biology. J Appl Physiol (1985 ) 91:534-551.

Hutcheson DA, Zhao J, Merrell A, Haldar M, Kardon G (2009). Embryonic and fetal limb myogenic cells are derived from developmentally distinct progenitors and have different requirements for beta-catenin. Genes Dev 23:997-1013.

Kuang S, Kuroda K, Le GF, Rudnicki MA (2007). Asymmetric self-renewal and commitment of satellite stem cells in muscle. Cell 129:999-1010.

Lewis A, Riddoch-Contreras J, Natanek SA, Donaldson A, Man WD, Moxham J, Hopkinson NS, Polkey MI, Kemp PR (2012). Downregulation of the serum response factor/miR-1 axis in the quadriceps of patients with COPD. Thorax 67:26-34.

McKinnell IW, Ishibashi J, Le GF, Punch VG, Addicks GC, Greenblatt JF, Dilworth FJ, Rudnicki MA (2008). Pax7 activates myogenic genes by recruitment of a histone methyltransferase complex. Nat Cell Biol 10:77-84.

Moss FP, Leblond CP (1971). Satellite cells as the source of nuclei in muscles of growing rats. Anat Rec 170:421-435.

Naguibneva I, Ameyar-Zazoua M, Polesskaya A, Ait-Si-Ali S, Groisman R, Souidi M, Cuvellier S, Harel-Bellan A (2006). The microRNA miR-181 targets the homeobox protein Hox-A11 during mammalian myoblast differentiation. Nat Cell Biol 8:278-284.

Nakajima N, Takahashi T, Kitamura R, Isodono K, Asada S, Ueyama T, Matsubara H, Oh H (2006). MicroRNA-1 facilitates skeletal myogenic differentiation without affecting osteoblastic and adipogenic differentiation. Biochem Biophys Res Commun 350:1006-1012.

O'Rourke JR, Georges SA, Seay HR, Tapscott SJ, McManus MT, Goldhamer DJ, Swanson MS, Harfe BD (2007). Essential role for Dicer during skeletal muscle development. Dev Biol 311:359-368.

Palacios D, Puri PL (2006). The epigenetic network regulating muscle development and regeneration. J Cell Physiol 207:1-11.

Parker MH, Seale P, Rudnicki MA (2003). Looking back to the embryo: defining transcriptional networks in adult myogenesis. Nat Rev Genet 4:497-507.

Perdiguero E, Sousa-Victor P, Ballestar E, Munoz-Canoves P (2009). Epigenetic regulation of myogenesis. Epigenetics 4:541-550. 
Puig-Vilanova E, Aguilo R, Rodriguez-Fuster A, Martinez-Llorens J, Gea J, Barreiro E (2014a). Epigenetic mechanisms in respiratory muscle dysfunction of patients with chronic obstructive pulmonary disease. PLoS One 9:e111514.

Puig-Vilanova E, Ausin P, Martinez-Llorens J, Gea J, Barreiro E (2014b). Do epigenetic events take place in the vastus lateralis of patients with mild chronic obstructive pulmonary disease? PLoS One 9:e102296.

Puig-Vilanova E, Martinez-Llorens J, Ausin P, Roca J, Gea J, Barreiro E (2015). Quadriceps muscle weakness and atrophy are associated with a differential epigenetic profile in advanced COPD. Clin Sci (Lond) 128:905-921.

Rao PK, Kumar RM, Farkhondeh M, Baskerville S, Lodish HF (2006). Myogenic factors that regulate expression of muscle-specific microRNAs. Proc Natl Acad Sci U S A 103:8721-8726.

Sacco A, Doyonnas R, Kraft P, Vitorovic S, Blau HM (2008). Self-renewal and expansion of single transplanted muscle stem cells. Nature 456:502-506.

Seale P, Sabourin LA, Girgis-Gabardo A, Mansouri A, Gruss P, Rudnicki MA (2000). Pax7 is required for the specification of myogenic satellite cells. Cell 102:777-786.

Shefer G, Van de Mark DP, Richardson JB, Yablonka-Reuveni Z (2006). Satellite-cell pool size does matter: defining the myogenic potency of aging skeletal muscle. Dev Biol 294:50-66.

Snow MH (1978). An autoradiographic study of satellite cell differentiation into regenerating myotubes following transplantation of muscles in young rats. Cell Tissue Res 186:535-540.

Tajbakhsh S (2009). Skeletal muscle stem cells in developmental versus regenerative myogenesis. J Intern Med 266:372-389.

Wang H, Garzon R, Sun H, Ladner KJ, Singh R, Dahlman J, Cheng A, Hall BM, Qualman SJ, Chandler DS, Croce CM, Guttridge DC (2008). NF-kappaB-YY1-miR-29 regulatory circuitry in skeletal myogenesis and rhabdomyosarcoma. Cancer Cell 14:369-381.

Wang L, Zhou L, Jiang P, Lu L, Chen X, Lan H, Guttridge DC, Sun H, Wang H (2012). Loss of miR-29 in myoblasts contributes to dystrophic muscle pathogenesis. Mol Ther 20:1222-1233.

Weintraub H, Tapscott SJ, Davis RL, Thayer MJ, Adam MA, Lassar AB, Miller AD (1989). Activation of muscle-specific genes in pigment, nerve, fat, liver, and fibroblast cell lines by forced expression of MyoD. Proc Natl Acad Sci U S A 86:5434-5438.

White RB, Bierinx AS, Gnocchi VF, Zammit PS (2010). Dynamics of muscle fibre growth during postnatal mouse development. BMC Dev Biol 10:21.

Yablonka-Reuveni Z (1995). Development and postnatal regulation of adult myoblasts. Microsc Res Tech 30:366-380.

Yablonka-Reuveni Z (2011). The skeletal muscle satellite cell: still young and fascinating at 50 . J Histochem Cytochem 59:1041-1059.

Yablonka-Reuveni Z, Day K, Vine A, Shefer G (2008). Defining the transcriptional signature of skeletal muscle stem cells. J Anim Sci 86:E207-E216.

Zhao Y, Samal E, Srivastava D (2005). Serum response factor regulates a muscle-specific microRNA that targets Hand2 during cardiogenesis. Nature 436:214-220. 
Dear Dr. Barreiro,

We have received the reports from our advisors on your revised manuscript, "EPIGENETIC REGULATION OF MUSCLE DEVELOPMENT", which you submitted to Journal of Muscle Research and Cell Motility.

Based on the advice received, I feel that your manuscript could be reconsidered for publication should you be prepared to incorporate major revisions. When preparing your revised manuscript, you are asked to carefully consider the reviewer comments which are attached, and submit a list of responses to the comments. The manuscript might easily be salvaged by seriously working on the weak parts.

Please also submit your response as separate submission item.

Please note: When uploading your revised files, please make sure only to submit your editable source files (i. E. Word, tex).

In order to submit your revised manuscript, please access the following web site:

http://jure.edmgr.com/

Your username is:

Your password is: $* * * * * * *$

We look forward to receiving your revised manuscript within eight weeks.

With kind regards,

Mathias Gautel, MD PhD

Editor in Chief

COMMENTS FOR THE AUTHOR:

We thank the Reviewer for their comments aimed at improving the review. We would like to point out that this review was commissioned by the journal to reflect an overview of one session in the EMC meeting in Montpellier in 2016. It is therefore aimed at a general audience and is limited scope. We note also that an updated PDF file that addressed some issues raised below was inadvertently not communicated. Replies to the comments are listed below.

\section{Reviewer \#2:}

Barreiro and Tajbaksh have submitted a revised version of a short review about the results presented at a recent meeting dealing the epigenetics of muscle regeneration. The authors have addressed all my concerns and improved the manuscript. Unfortunately, the revision did not eradicate all flaws and new ones were introduced.

1.) The description of euchromatin and heterochromatin, which was newly introduced in the revision, is very naïve. Heterochromatin is not only involved in the regulation of gene transcription but also in genome stability, etc. The authors should rephrase the sentence.

There are many features that characterise heterochromatin. Since this review is not centered on describing chromatin biology in detail, some, but not all features of euchromatin and heterochromatin are now added to the text. Indeed, the notion that heterochromatin leads to lack of gene expression has been challenged by examples of transcripts appearing from heterochromatic regions. These features, in addition to genome stability as the Reviewer indicates, sub-nuclear localization, and satellite sequences, are some features characterise heterochromatin. We point out that in the first paragraph of the introduction, the role of chromatin in genome stability was already made.

2.) The sentence "Specifically, chromatin is composed by nucleosomes and a core of histone proteins, identified as H2A, H2B, H3, and H4." does not make much sense, What do the authors think nucleosomes are made of? (In addition, one of my fellow reviewers specifically ask to 
change BY to OF, which is of course true. Nucleosomes do "make" chromatin as insinuated by using BY.)

We regret the inappropriate use of the preposition that appears to have created confusion in the sentence. This has been corrected.

3.) The definition of epigenetic mechanism varies from author to author. I personally do not think that miRNAs are necessarily part of epigenetic mechanisms (miRNAs regulate RNA degradation in the cytoplasm and mRNA translation) but I accept different views. However, it is certainly wrong to write "A few examples of these epigenetic biochemical modifications are the following:" and then list miRNAs. miRNAs are a biochemical modification, really?

Indeed, the loose use of the terms "epigenetics" and "epigenomics" irritate some researchers, whereas others are not as obsessive. We prefer to avoid this controversy that will distract from the general messages of the review. The reference to biochemical has been removed.

4.) When comparing embryonic and adult myogenesis the authors write "Despite certain differences such as the lack of a primary myogenesis wave (Tajbakhsh, 2009), embryonic muscle development and postnatal myogenesis share molecular and functional similarities, which are seen in both embryonic myogenic precursors (myoblasts) and satellite cells (Parker et al, 2003). Of course, there are many similarities but also differences between embryonic and adult myogenesis but the "the lack of a primary myogenesis wave" is certainly not the defining criterion that distinguishes both processes. It is also not clear what is meant: The de novo formation of muscle cells from mesodermal cells during embryonic development? That is somewhat trivial.

The point of this phrase was that some features of embryonic myogenesis are recapitulated, but others are not. This part has been modified.Moreover, it should also be mentioned that the sentence "The de novo formation of muscle cells from mesodermal cells during embryonic development? " has not been found in the document submitted by the authors.

5.) The authors write "Interestingly, satellite cells also have the ability to self-renew to form tissue-specific stem cells (Collins et al, 2005;Sacco et al, 2008)." This does not make sense. Satellite cells are generally accepted to represent muscle stem cells and self-renewal is an essential feature of stem cells. What do the authors want to say when writing satellite cells form tissue-specific stem cells?

This phrase has been compacted and modified.

6.) The authors write "The basic helix-loop-helix transcription factor MyoD plays a key role in muscle differentiation as it is one of the earliest markers of myogenic commitment." MyoD plays a key role in muscle differentiation because it is a marker? The authors certainly have something different in mind. Being a marker is certainly not an indicator of functional relevance.

This sentence has been rephrased to replace "as" with "and".

7) Further on: The authors write that MyoD MAY bind to promoters to regulate gene expression and MAY transform different cell types into myotubes. There is overwhelming evidence that MyoD directly regulates gene expression and there is no doubt that MyoD reprograms several cell types to myoblasts. However, MyoD does NOT reprogram non-myogenic cells directly to myotubes, which form as a result of myoblast fusion.

The unfortunate use of the word "may" has created confusion - it was used in the context of "opportunity" rather than "contingency" as in some other languages of latin origin. This formulation has been changed, as well as the one referring to myotubes.

8.) I asked for a more precise definition of the role of Pax3. The revised paragraph is not overtly wrong but misleading. Inactivation of Pax3 is NOT preventing the onset of myogenesis. Maybe 
I am too picky here but I am pretty sure that the authors are able to provide a more accurate description.

Corrections have been made to this part of the text.

9.) The authors claim that the English was polished, which I fail to see. There are still many rather odd sentences in the manuscript.

Other changes have been made to the manuscript and we hope that this has improved the reading.

10.) The figure is more or less useless and should be replaced by a more instructive one.

The figure has been removed. 


\section{LETTER TO THE EDITOR}

Dear Dr. Barreiro,

We have received the reports from our advisors on your revised manuscript, "EPIGENETIC REGULATION OF MUSCLE DEVELOPMENT", which you submitted to Journal of Muscle Research and Cell Motility.

Based on the advice received, I feel that your manuscript could be reconsidered for publication should you be prepared to incorporate major revisions. When preparing your revised manuscript, you are asked to carefully consider the reviewer comments which are attached, and submit a list of responses to the comments. The manuscript might easily be salvaged by seriously working on the weak parts.

Please also submit your response as separate submission item. Please note: When uploading your revised files, please make sure only to submit your editable source files (i. E. Word, tex).

In order to submit your revised manuscript, please access the following web site:

http://jure.edmgr.com/

Your username is: ebarreiro@imim.es

Your password is: available at this link http://jure.edmgr.com/Default.aspx?pg=accountFinder.aspx\&firstname=Esther\&lastname=Ba rreiro\&email_address=ebarreiro@imim.es

We look forward to receiving your revised manuscript within eight weeks.

With kind regards,

Mathias Gautel, MD PhD

Editor in Chief

\section{Dear Editor,}

Please find attached revisions of our review. As we indicated previously, we were commissioned to submit a mini-commentary related to one session at the EMC conference in Montpellier. We appreciate the comments of the referees that helped improve the mini-review, however, it appears that in the second round we have become unstuck with one referee who is perhaps unclear on the initial objective of this exercise. The reading of the feedback reveals an over-reaction even to the use of prepositions. We do not feel that this referee understands the objective of this exercise.

We would like to insist that given the brevity and focused nature of this commentary, targeted to a general audience and reflecting one session of the EMC conference, it should be considered that the scope is limited.

We will be looking forward to hearing from you soon. We also thank you in advance.

Sincerely,

Dr. Esther Barreiro and Dr. Tajbakhsh 


\section{EPIGENETIC REGULATION OF MUSCLE DEVELOPMENT}

1,2,3Esther Barreiro and ${ }^{4}$ Shahragim Tajbakhsh

${ }^{1}$ Respiratory Medicine Department, Muscle Wasting and Cachexia in Chronic Respiratory

Diseases and Lung Cancer Research Group, Institute of Medical Research of Hospital del Mar (IMIM)-Hospital del Mar, Parc de Salut Mar, Barcelona Biomedical Research Park (PRBB), Barcelona, Spain.

${ }^{2}$ Department of Health Sciences (CEXS), Universitat Pompeu Fabra, Barcelona, Spain. ${ }^{3}$ Centro de Investigación en Red de Enfermedades Respiratorias (CIBERES), Instituto de Salud Carlos III (ISCIII), Barcelona, Spain.

${ }^{4}$ Institut Pasteur, Stem Cells \& Development, CNRS URA 3738, Dept. of Developmental \& Stem Cell Biology, 25 rue du Dr. Roux, 75724 Paris Cedex 15, France

Corresponding author: Dr. Esther Barreiro

Running title: Epigenetics in myogenesis

Word count: 2,15261 


\section{ABSTRACT}

In eukaryote cells, chromatin appears in several forms and is composed of is defined as eondensed-genomic DNA, protein and RNApresent in the nuclets. The protein content of cehromatin is composed primarily of core histones that are packaged into nucleosomes and a core of histone proteinsresulting in the condensation of the DNA. Several epigenetic mechanisms regulate the stability of the nucleosomes and the protein-protein interactions that modify the transcriptional activity of the DNA. Interestingly, epigenetic control of gene expression has recently emerged as a relevant mechanism involved in the regulation of many different biological processes including that of muscle development, muscle mass maintenance, function, and phenotype in health and disease. Recent investigations have shed light into the epigenetic control of biological mechanisms that are key regulators of embryonic muscle development and postnatal myogenesis. In the present review article, we provide a summary of the contents discussed in session 08, titled "Epigenetics of muscle regeneration", during the course of the $45^{\text {th }}$ European Muscle Conference, which was celebrated in Montpellier (France) in September 2016. The main theme of that session was to highlight the most recent progress on the role of epigenetics in the regulation of muscle development and regeneration. The current mini-review has been divided into two major sections. On the one hand, a brief introduction on the topic of myogenesis is offered for the nonspecialized reader. On the other, a brief overview of the most relevant epigenetic players that have been shown to control muscle development and regeneration is given.

Word count: 223238

KEY WORDS: epigenetics; skeletal muscles; embryonic muscle development; muscle repair and postnatal myogenesis
Formatted: Font color: Auto

Formatted: Font color: Auto

Formatted: Font color: Auto

Formatted: Font color: Auto

Formatted: Font color: Auto

Formatted: Font color: Auto 


\section{INTRODUCTION}

In eukaryotic cells, DNA, proteins, and RNA form chromatin, whose structure clearly depends on the cell cycle.Packaging of DNA into a rather-compact structure, to control gene transcription, and to protect DNA from damage are among the most relevant functions of chromatin in eukaryotic cells. Chromatin that is structurally loose in order to-allows gene transcription (euchromatin), whereas highly condensed chromatin (heterochromatin) becomes more condensed and is generally associated with structural proteins (heterochromatin) when-repression of gene transcription is requiredand genome stability. Specifically, chromatin is composed by of nucleosomes- that are comprised ofand a cere of histone proteins, identified as ztwo copies of each of $\mathrm{H} 2 \mathrm{~A}, \mathrm{H} 2 \mathrm{~B}, \mathrm{H} 3$, and $\mathrm{H} 4$, and these structures are compacted into chromatin by linker histones such as H1. Epigenetic control of cell behaviours, defined as the process whereby gene expression is regulated by heritable mechanisms that do not affect DNA sequence, regulates-can affect cell growth and differentiation and-and impact on the underlies the pathophysiology of chronic and acute eonditionsdiseases. Several epigenetic mechanisms regulate the stability of the nucleosomes and the protein-protein interactions that modify the transcriptional activity of the DNA (Baar, 2010). A few examples of these-epigenetic biochemical-modifications are the followinginclude: 1) non-coding RNAs including microRNAs, 2) histone acetylation and deacetylation, 3) histone methylation, and 4) DNA methylation. Interestingly, epigenetic control of gene expression has recently emerged as a relevant mechanism involved in the regulation of many different biological processes including that of muscle mass, function, and phenotype in health and disease (Donaldson et al, 2013;Lewis et al, 2012;Puig-Vilanova et al, 2014a;Puig-Vilanova et al, 2014b;Puig-Vilanova et al, 2015). In the present review-article, a summary we summarize- - f the the contents discussed in session 08 ,
Formatted: Font color: Auto

Formatted: Font color: Auto

Formatted: Font color: Auto Field Code Changed 
titledthe "Epigenetics of muscle regeneration" session at, during the eourse of the $45^{\text {th }}$ European Muscle Conference-is given below. The main theme of that session was to highlight the most recent progress on the role of epigenetics in the regulation of the process of muscle regeneration. As such, the current mini-review has been divided into two major sections: i). On the one hand, a brief introduction on the topic of muscle development and postnatal myogenesis; and ii)-is given. On the other hand, the most relevant epigenetic players that control muscle development and regeneration-are being reviewed.

\section{MUSCLE DEVELOPMENT}

During embryonic myogenesis, paraxial mesoderm-derived structures derived cells generate the first primary muscle fibers of the body that act as a scaffold for the formation of secondary fibers. The latter appear during foetal development and they continue to grow by nuclear accretion until perinatal stages (Comai and Tajbakhsh, 2014)(Comai and Tajbakhsh, 2014).(Bentzinger et al, 2012). A reservoir of myogenic cells is subsequently allocated during the perinatal period and it will give rise to the Satellite cells, which are tissue-specific stem cellssatellite (stem) cells, lead to muscle growth and repair following injury. Their-The privileged position of these cells on the surface of the myofiber, beneath the basal lamina, enables them to respond to mechanical, structural, and functional stimuli of skeletal muscle fibers-tostart pestnatal myogenesis. Despite certain differences such as the lack of a primary myogenesis wave (Tajbakhsh, 2009), embryonic muscle development and postnatal myogenesis share molecular and functional similarities, which are seen in both embryonic myogenic precursors (myoblasts) and satellite cells (Parker et al, 2003). In-During the early juvenile growth phase,, when muscle expands, satellite cells proliferate and add nuclei
Formatted: Font color: Auto

Formatted: Font color: Auto

Formatted: Font color: Auto

Formatted: Font color: Auto

Formatted: Font color: Auto

Formatted: Font color: Auto

Formatted: Font color: Auto

Formatted: Font color: Auto

Formatted: Font color: Auto

Formatted: Font color: Auto

Formatted: Font color: Auto 
to the growing myofibers; subsequently ${ }_{2}$ proliferation gradually declines gradually, as myofibers increase in diameter (Moss and Leblond, 1971; White et al, 2010)(Moss and Leblond, 1971) (REF: White et al. BMC Dev Biol. 2010; PMHD: 20175910). In adult muscles, satellite cells remain quiescent until muscle injury triggers their activation (Snow, 1978; Yablonka-Reuveni, 1995). Despite certain differences such as the lack of a primary myogenesis wave (Tajbakhsh, 2009), prenatal and postnatal myogenesis share some molecular and functional similarities including the sequential appearance of transcription factors from an upstream state (ex. Pax7, Myf5) to a committed and differentiated state (ex. MyoD, Myogenin) (Parker et al, 2003). In the same adult muscles, s[- Small injuries, such as those ef-promoted by daily life activities, lead to minimal proliferation, whereas major lesions induce longer proliferation periods before differentiation may take place (Yablonka-Reuveni, 2011). Signals from the muscle niche $_{2}$ and-microvasculture, and-local inflammation (Yablonka-Reuveni, 2011) and systemic factors activate satellite cells (Carlson et al, 2009; Conboy et al, 2005).

In response to muscle injury, satellite cells contribute to repair of damaged fibers while new myofibers are also formed following a program of cell division and fusion of myoblasts (Yablonka-Reuveni et al, 2008). A-very tight program number of regulatory factors is in-control of-satellite cell behaviour from quiescence, entry into proliferation, maintenance of the cell cycle, and differentiation, and subsequent self-renewal following return to homeostasis (Yablonka-Reuveni et al, 2008)- Interestingly, satellite cells also have the ability to self-renew to form tissue-specific stem cells-(Collins et al, 2005;Sacco et al, 2008). It has been estimated that in theduring early postnatal growth, satellite cells represent $30 \%$ of the nuclei, while they only constitute $2 \%-7 \%$ of nuclei in healthy adult skeletal muscles (Halevy et al, 2004;Hawke and Garry, 2001). The
Formatted: Font color: Auto

Formatted: Font color: Auto

Formatted: Font color: Auto

Field Code Changed

Formatted: Font color: Auto

Formatted: Font color: Auto, Highlight

Formatted: Font color: Auto

Formatted: Font color: Auto

Field Code Changed

Formatted: Font color: Auto

Formatted: Font color: Auto

Field Code Changed

Formatted: Font color: Auto

Formatted: Font color: Auto

Formatted: Font color: Auto

Field Code Changed

Formatted: Font color: Auto

Field Code Changed

Formatted: Font color: Auto

Formatted: Font color: Auto

Field Code Changed

Formatted: Font color: Auto

Formatted: Font color: Auto

Field Code Changed

Formatted: Font color: Auto

Formatted: Font color: Auto

Field Code Changed

Formatted: Font color: Auto

Formatted: Font color: Auto

Formatted: Font color: Auto

Formatted: Font color: Auto, French (France)

Field Code Changed

Formatted: Font color: Auto

Field Code Changed

Formatted: Font color: Auto, French (France)

Formatted: Font color: Auto

Formatted: Font color: Auto

Field Code Changed

Formatted: Font color: Auto 


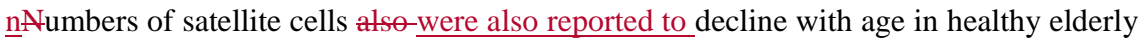
subjects (Collins et al, 2007; Shefer et al, 2006).

The basic helix-loop-helix transcription factor MyoD plays a key role in muscle

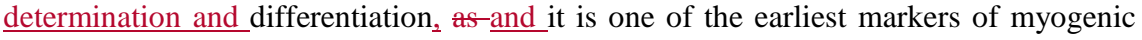
commitment. Notably, seminalPrevious experiments have also-demonstrated that MyoD may also-can transform differenta variety of cell types, including fibroblasts, into myoblasts that will subsequently fuse to form myotubes, (Davis et al, 1987). In quiescent satellite cells that are characterized by the expression of Pax7, MyoD is expressed in very low levelsprotein is generally not detectable. Following their activation, MyoD transcription and protein levels increase dramatically (Comai and Tajbakhsh, 2014)(Comai and Tajbakhsh, 2014), while they go up in response to tissue damage and exercise. In muscle development, its main function is to-commit mesoderm cells to a skeletal muscle cell lineage. As a transcription factor, MyoD may also binds to gene enhancers and promoters to regulate myogenesis,-Previous experiments have alse demola

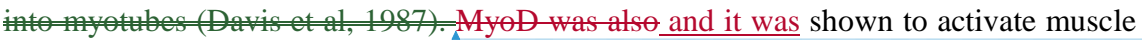
genes in a variety of differentiated cell lines from several species (chicken, human, and rat), which suggests that MyoD is a critical transeription factor required for terminal muscle cell differentiation (Weintraub et al, 1989). Myf5 and Mrf4 also act as determination genes, whereas Myogenin is a differentiation factor - and each of these factors that belong to the MyoD family have unique and overlapping properties as well as expression patterns during embryogenesis (Comai and Tajbakhsh, 2014). Moreover, in non-muscle cell lines, myogenic commitment features may also be induced by other myogenic basic helix loop helix factors such as Myf5, Myogenin, and Mrf4 (Braun et at, 1990;Edmondsen and O1sen, 1989).
Formatted: Font color: Auto

Formatted: Font color: Auto

Field Code Changed

Formatted: Font color: Auto

\section{Field Code Changed}

Formatted: Font color: Auto

Formatted: Font color: Auto

Field Code Changed

Formatted: Font color: Auto

Formatted: Font color: Auto

Field Code Changed

Field Code Changed 
Early striated muscle development arising from somites in the body trunk is the result of the action of the paired-homeobox transcription factors $\operatorname{Pax} 3$ and $\operatorname{Pax} 7$ genes. Importantly, genetic ablation of the Pax3 lineage was embryonically lethal and prevented the emergence of Pax7-positive cells, while ablation of Pax7-expressing cells enly causedresulted in the appearance of smaller muscles with fewer myofibers in the limbs at birth (Hutcheson et al, 2009; Seale et al, 2000). Pax3 is a key factor in the regulation and onset of myogenesis for skeletal muscles in the trunk and limbs where some downstream targets include MyoD and the tyrosine kinase receptor c-met. As at transcription factor, $c-$ met and $M y_{0} D$ seem to be the targets that may initiate myogenesis in skeletal muscles. Interestingly, Although its expression is not restricted to skeletal muscle, Pax3 is expressed well before the onset of myogenesis, in presomitic mesoderm, and subsequently its expression is restricted to the epithelial very early embryonic phases as in the dermatomyotome dermomyotome of the somite that gives rise to multiple cell types including all of the myogenic cells of the trunk and limbs. of paraxial mesoderm, contributing to early striated muscle development. HowererNotably, Pax3 is not expressed in head derived muscle progenitors. In this case, Tbx1 and Pitx2, among other transcription factors, play critical roles in establishing myogenesis from cranial mesoderm (Comai and Tajbakhsh, 2014).

\section{EPIGENETIC REGULATION OF MYOGENESIS/ MUSCLE DEVELOPMENT}

Epigenetic events regulate the quiescentee and proliferation states preventing the differentiation-of muscle satellite cells and their progeny. In this regardcontext, DNA methylation is a major repressive mechanism of muscle satellite cell differentiation (Palacios and Puri, 2006;Bigot et al, 2015), whereas demethylation along with $M y o D$ and Myogenin are required for the initiation of their-the differentiation program

Formatted: Font color: Auto

Field Code Changed

Formatted: Font: Italic, Font color: Auto Formatted: Font color: Auto

Formatted: Font color: Auto

Field Code Changed

Field Code Changed 
(Palacios and Puri, 2006). Mechanisms that act on chromatin-associated histones are also involved in the control of muscle satellite cell quiescence and proliferation. Histone acetylation is a transient, enzymatically controlled biochemical process, and the eemmenest-most common posttranslational modification of histone proteins. The acetyl group from acetyl-CoA is transferred to a lysine residue, thus converting its basic side chain into a neutral residue, which thereby resultings in a ratheran open chromatin (euchromatin) structure that is transcriptionally active. Deacetylation reverses this process, leading to a closed chromatin structure (heterochromatin) that is generally transcriptionally blockedrepressed. Histone deacetylases (HDACs) are enzymes that remove acetyl groups from lysine residues of histone proteins, allowing the histones to condense DNA. HDACs may also interact with chromatin through association with other histone-modifying proteins and transcription factors, and they may-also remove lysine residues from non-histone proteins. Importantly, in proliferating myoblasts, HDAC1 $\underline{-5}$, HDAC2, HDAC3, HDAC4, and HDAC5 and Sirtuins maintain transcription factors in a deacetylated state, especially-particularly when differentiation-promoting signals are absent. Other epigenetic mechanisms such as the expression of specific histone isoforms or the replacement of canonical histones with histone variants may alsecan regulate muscle satellite cell quiescence and proliferation as well as_(Perdiguero et al, 2009).

Epigenetic mechanisms also control the gene expression program during muscle differentiation. In this regard, genes that are actively transcribing are marked by $\mathrm{H} 3 \mathrm{~K} 4 \mathrm{me} 3$, whereas those ready to be transcribed are-can be marked by H3K4me2 (Guenther et al, 2007). As such, Pax7 was shown to bind to $\mathrm{H} 3 \mathrm{~K} 4 \mathrm{me} 2$ regulatory elements in target genes such as $M y f 5$ in satellite cells (Kuang et al, 2007;McKinnell et al, 2008). Interestingly, this binding leads to the recruitment of TRxG histone
Field Code Changed

Formatted: Font color: Auto

Formatted: Font color: Auto

Field Code Changed

Formatted: Font color: Auto

Formatted: Font color: Auto

Field Code Changed

Field Code Changed 
methyltransferase complex, which in turn will result in elevated $\mathrm{H} 3 \mathrm{~K} 4$ trimethlyation on the transcription start site (Kuang et al, 2007;McKinnell et al, 2008). Finally, inactivation of HDACs and Sirtuins together with the concomitant activation of HTAs will allow the activation of transcription factors and nucleosomes for the muscle differentiation program to proceed.

The non-coding microRNAs also play a relevantan important role in the control of muscle development. Interestingly, miRNAs, encoded by eukaryotic nuclear DNA, are non-coding single-stranded RNA molecules (18-24 nucleotides) that function in the post-transcriptional regulation of gene expression. They exert their action via basepairing with complementary sequences of mRNA molecules which result in gene silencing via translational repression or target degradation. Importantly, miRNAs may have different mRNA targets, and a given mRNA may also be targeted by multiple miRNAs in a similar fashion. It is well known that miRNAs regulate many cellular processes and have a role in disease pathogenesis, and muscle development. Although microRNAs regulate a wide variety of biological processes in different tissues, tissuespecificity also exists for certain microRNAs. As suchFor example, miR-1, miR-133, and miR-206 have been shown to be abundantly expressed within -in skeletal muscles and they are defined as muscle-specific microRNAs (myomiRs). Several steps of muscle development are tightly regulated by these muscle-specific microRNAs. Despite the potential limitations of the findings reported so far, as a result of the in vitro and/or the use of genetically modified mice, a brief overview ofn how microRNAs may $\underline{\text { can }}$ regulate myogenesis is provided below.

Perinatal lethality, reduced muscle mass, and abnormal myofiber structure has been was shown as a result ofreported following inactivation of Dicer, which leads to the accumulation of unprocessed pre-miRNAs (O'Rourke et al, 2007) thereby pointing

\section{Field Code Changed}

Formatted: Font color: Auto

Formatted: Font color: Auto

Formatted: Font color: Auto

Formatted: Font color: Auto 
to a critical role for myomiRs in skeletal muscle development. The molecules miR-1 and miR-133, which are localized within the same chromosomal locus and are cotranscribed, become two independent mature miRNAs with empletely differentdistinct biological functions in the regulation of skeletal muscle proliferation and differentiation. Interestingly, miR-133 stimulates myoblast proliferation by repressing the serum response factor ${ }_{2}$ and inhibits myotube formation, whereas miR-1 promotes muscle cell differentiation as a result of targeting HDAC4 targeting (Chen et al, 2006). Similarly to the action of miR-1, miR-206 was reported to promote myotube formation by targeting DNA polymerase alpha (p180 subunit), leading to the inhibition of DNA synthesis and cell cycle withdrawal, as well as to terminal cell differentiation (Deato et al, 2008; Nakajima et al, 2006). However, a recent report showed that deletion of mifR206/133b resulted in no major defects in developmental and adult myogenesis, or during muscle regeneration (Boettger et al, 2014). The authors proposed that functional compensation by miRł1/133a might explain this surprising lack of a phenotype. In others studies, miR-1 was suggested to target the insulin-like growth factor-1 (IGF-1) pathway, while inducing a feedback loop between miR-1 expression and the IGF-1 signal transduction cascade (Elia et al, 2009). Interestingly, dowregulation downregulation of connexin 43-dependent gap junctional communication by miR-1 and miR-206 also appears to regulate innervation of muscle fibers (Anderson et al, 2006).

Importantly, other microRNAs ubiquitously expressed in tissues may also be expressedplay a role in muscles for the regulation of -skeletal muscle development-and phenotype. In this regardcontext, myoblast differentiation through the downregulation of Paired the paired-box protein Pax7 was reported to be mediated by miR-206 and miR-486 (Dey et al, 2011). Expression of these two microRNAs favors differentiation in myoblasts, whereas inhibition of their expression results in maintenance of Pax7

Field Code Changed

Field Code Changed

Formatted: Font color: Auto

Field Code Changed

Formatted: Font color: Auto

Formatted: Font color: Auto

Field Code Changed

Field Code Changed

Field Code Changed 
activity, which delayed differentiation. In embryonic myotomes, satellite cells, and adult muscle fibers, miR-27, which_(targets Pax3), is also expressed (Crist et al, 2009). Interestingly, myogenic differentiation oceurs in part by targeting Pax3 by miR 27 (Kassar Duchessey et al, 2005). Additionally, MyoD may alsewas reported to be induced by the action of miR-181, which targets the repressor of myoblast terminal differentiation Hox-A11 (Naguibneva et al, 2006). The action of miR-29 may alsecan favor muscle development through the feedback inhibition of transcriptional repressors such as Yin Yang (YY)1 (Wang et al, 2008). Notably, loss of miR-29 was also shown to induce the transdifferentiation of myoblasts into myofibroblasts, and transforming growth factor (TGF)-beta signaling negatively regulated its expression (Wang et al, 2012). Indeed, miR-29 expression levels decreased in dystrophic muscles from $m d x$ mice (an experimental model of Duchene muscular dystrophy) in the same report (Wang et al, 2012). Importantly_RemarkablyNotably, muscle-specific microRNAs may alsewere reported to be regulated by the action of muscle-specific transcription factors such as MyoD, Myogenin, myocyte-enhancing factor (MEF)2, and the serum response factor (Rao et al, 2006;Zhao et al, 2005). Finally, as-given the wide number of transcriptional targets for miRNAs, more studies are necessary beforeabovementioned, given the nature of the reported stulies, all these findings should be taken cautiously at the time of designing potential therapeutic strategies in patients with muscle diseases.

\section{CONCLUDING REMARKS}

Epigenetics play a paramount role in the regulation of embryonic muscle development andprenatal and postnatal myogenesis-(Figure 1). Future studies will shed light into additional mechanisms that may help thoroughly understand the process of muscle development and repair following injury-in adult museles. Potential therapeutic 
strategies may alsøwill likely emerge from theonce we develop a better understanding of the biological events that underlie myogenesis and muscle repair. 
Anderson C, Catoe H, Werner R (2006). MIR-206 regulates connexin43 expression during Field Code Changed skeletal muscle development. Nucleic Acids Res 34:5863-5871.

\section{Formatted: Space After: $12 \mathrm{pt}$}

Baar K (2010). Epigenetic control of skeletal muscle fibre type. Acta Physiol (Oxf) 199:477487.

Bigot A, Duddy WJ, Ouandaogo ZG, Negroni E, Mariot V, Ghimbovschi S, Harmon B, Wielgosik A, Loiseau C, Devaney J, Dumonceaux J, Butler-Browne G, Mouly V, Duguez S (2015). Age-Associated Methylation Suppresses SPRY1, Leading to a Failure of Re-quiescence and Loss of the Reserve Stem Cell Pool in Elderly Muscle. Cell Rep 13:1172-1182.

Boettger T, Wust S, Nolte H, Braun T (2014). The miR-206/133b cluster is dispensable for development, survival and regeneration of skeletal muscle. Skelet Muscle 4:23.

Carlson ME, Conboy MJ, Hsu M, Barchas L, Jeong J, Agrawal A, Mikels AJ, Agrawal S, Schaffer DV, Conboy IM (2009). Relative roles of TGF-betal and Wnt in the systemic regulation and aging of satellite cell responses. Aging Cell 8:676-689.

Chen JF, Mandel EM, Thomson JM, Wu Q, Callis TE, Hammond SM, Conlon FL, Wang DZ (2006). The role of microRNA-1 and microRNA-133 in skeletal muscle proliferation and differentiation. Nat Genet 38:228-233.

Collins CA, Olsen I, Zammit PS, Heslop L, Petrie A, Partridge TA, Morgan JE (2005). Stem cell function, self-renewal, and behavioral heterogeneity of cells from the adult muscle satellite cell niche. Cell 122:289-301.

Collins CA, Zammit PS, Ruiz AP, Morgan JE, Partridge TA (2007). A population of myogenic stem cells that survives skeletal muscle aging. Stem Cells 25:885-894.

Comai G, Tajbakhsh S (2014). Molecular and cellular regulation of skeletal myogenesis. Curr Top Dev Biol 110:1-73.

Conboy IM, Conboy MJ, Wagers AJ, Girma ER, Weissman IL, Rando TA (2005). Rejuvenation of aged progenitor cells by exposure to a young systemic environment. Nature 433:760-764.

Crist CG, Montarras D, Pallafacchina G, Rocancourt D, Cumano A, Conway SJ, Buckingham M (2009). Muscle stem cell behavior is modified by microRNA-27 regulation of Pax3 expression. Proc Natl Acad Sci U S A 106:13383-13387.

Davis RL, Weintraub H, Lassar AB (1987). Expression of a single transfected cDNA converts fibroblasts to myoblasts. Cell 51:987-1000.

Deato MD, Marr MT, Sottero T, Inouye C, Hu P, Tjian R (2008). MyoD targets TAF3/TRF3 to activate myogenin transcription. Mol Cell 32:96-105

Dey BK, Gagan J, Dutta A (2011). miR-206 and -486 induce myoblast differentiation by downregulating Pax7. Mol Cell Biol 31:203-214.

Donaldson A, Natanek SA, Lewis A, Man WD, Hopkinson NS, Polkey MI, Kemp PR (2013). Increased skeletal muscle-specific microRNA in the blood of patients with COPD. Thorax 68:1140-1149. 
Elia L, Contu R, Quintavalle M, Varrone F, Chimenti C, Russo MA, Cimino V, De ML, Frustaci A, Catalucci D, Condorelli G (2009). Reciprocal regulation of microRNA-1 and insulin-like growth factor-1 signal transduction cascade in cardiac and skeletal muscle in physiological and pathological conditions. Circulation 120:2377-2385.

Guenther MG, Levine SS, Boyer LA, Jaenisch R, Young RA (2007). A chromatin landmark and transcription initiation at most promoters in human cells. Cell 130:77-88.

Halevy O, Piestun Y, Allouh MZ, Rosser BW, Rinkevich Y, Reshef R, Rozenboim I, Wleklinski-Lee M, Yablonka-Reuveni Z (2004). Pattern of Pax7 expression during myogenesis in the posthatch chicken establishes a model for satellite cell differentiation and renewal. Dev Dyn 231:489-502.

Hawke TJ, Garry DJ (2001). Myogenic satellite cells: physiology to molecular biology. J Appl Physiol (1985 ) 91:534-551.

Hutcheson DA, Zhao J, Merrell A, Haldar M, Kardon G (2009). Embryonic and fetal limb myogenic cells are derived from developmentally distinct progenitors and have different requirements for beta-catenin. Genes Dev 23:997-1013.

Kuang S, Kuroda K, Le GF, Rudnicki MA (2007). Asymmetric self-renewal and commitment of satellite stem cells in muscle. Cell 129:999-1010.

Lewis A, Riddoch-Contreras J, Natanek SA, Donaldson A, Man WD, Moxham J, Hopkinson NS, Polkey MI, Kemp PR (2012). Downregulation of the serum response factor/miR-1 axis in the quadriceps of patients with COPD. Thorax 67:26-34.

McKinnell IW, Ishibashi J, Le GF, Punch VG, Addicks GC, Greenblatt JF, Dilworth FJ, Rudnicki MA (2008). Pax7 activates myogenic genes by recruitment of a histone methyltransferase complex. Nat Cell Biol 10:77-84.

Moss FP, Leblond CP (1971). Satellite cells as the source of nuclei in muscles of growing rats. Anat Rec 170:421-435.

Naguibneva I, Ameyar-Zazoua M, Polesskaya A, Ait-Si-Ali S, Groisman R, Souidi M, Cuvellier S, Harel-Bellan A (2006). The microRNA miR-181 targets the homeobox protein Hox-A11 during mammalian myoblast differentiation. Nat Cell Biol 8:278-284.

Nakajima N, Takahashi T, Kitamura R, Isodono K, Asada S, Ueyama T, Matsubara H, Oh H (2006). MicroRNA-1 facilitates skeletal myogenic differentiation without affecting osteoblastic and adipogenic differentiation. Biochem Biophys Res Commun 350:1006-1012.

O'Rourke JR, Georges SA, Seay HR, Tapscott SJ, McManus MT, Goldhamer DJ, Swanson MS, Harfe BD (2007). Essential role for Dicer during skeletal muscle development. Dev Biol 311:359-368.

Palacios D, Puri PL (2006). The epigenetic network regulating muscle development and regeneration. J Cell Physiol 207:1-11.

Parker MH, Seale P, Rudnicki MA (2003). Looking back to the embryo: defining transcriptional networks in adult myogenesis. Nat Rev Genet 4:497-507.

Perdiguero E, Sousa-Victor P, Ballestar E, Munoz-Canoves P (2009). Epigenetic regulation of myogenesis. Epigenetics 4:541-550. 
Puig-Vilanova E, Aguilo R, Rodriguez-Fuster A, Martinez-Llorens J, Gea J, Barreiro E (2014a). Epigenetic mechanisms in respiratory muscle dysfunction of patients with chronic obstructive pulmonary disease. PLoS One 9:e111514.

Puig-Vilanova E, Ausin P, Martinez-Llorens J, Gea J, Barreiro E (2014b). Do epigenetic events take place in the vastus lateralis of patients with mild chronic obstructive pulmonary disease? PLoS One 9:e102296.

Puig-Vilanova E, Martinez-Llorens J, Ausin P, Roca J, Gea J, Barreiro E (2015). Quadriceps muscle weakness and atrophy are associated with a differential epigenetic profile in advanced COPD. Clin Sci (Lond) 128:905-921.

Rao PK, Kumar RM, Farkhondeh M, Baskerville S, Lodish HF (2006). Myogenic factors that regulate expression of muscle-specific microRNAs. Proc Natl Acad Sci U S A 103:8721-8726.

Sacco A, Doyonnas R, Kraft P, Vitorovic S, Blau HM (2008). Self-renewal and expansion of single transplanted muscle stem cells. Nature 456:502-506.

Seale P, Sabourin LA, Girgis-Gabardo A, Mansouri A, Gruss P, Rudnicki MA (2000). Pax7 is required for the specification of myogenic satellite cells. Cell 102:777-786.

Shefer G, Van de Mark DP, Richardson JB, Yablonka-Reuveni Z (2006). Satellite-cell pool size does matter: defining the myogenic potency of aging skeletal muscle. Dev Biol 294:50-66.

Snow MH (1978). An autoradiographic study of satellite cell differentiation into regenerating myotubes following transplantation of muscles in young rats. Cell Tissue Res 186:535-540.

Tajbakhsh S (2009). Skeletal muscle stem cells in developmental versus regenerative myogenesis. J Intern Med 266:372-389.

Wang H, Garzon R, Sun H, Ladner KJ, Singh R, Dahlman J, Cheng A, Hall BM, Qualman SJ, Chandler DS, Croce CM, Guttridge DC (2008). NF-kappaB-YY1-miR-29 regulatory circuitry in skeletal myogenesis and rhabdomyosarcoma. Cancer Cell 14:369-381.

Wang L, Zhou L, Jiang P, Lu L, Chen X, Lan H, Guttridge DC, Sun H, Wang H (2012). Loss of miR-29 in myoblasts contributes to dystrophic muscle pathogenesis. Mol Ther 20:1222-1233.

Weintraub H, Tapscott SJ, Davis RL, Thayer MJ, Adam MA, Lassar AB, Miller AD (1989). Activation of muscle-specific genes in pigment, nerve, fat, liver, and fibroblast cell lines by forced expression of MyoD. Proc Natl Acad Sci U S A 86:5434-5438.

White RB, Bierinx AS, Gnocchi VF, Zammit PS (2010). Dynamics of muscle fibre growth during postnatal mouse development. BMC Dev Biol 10:21.

Yablonka-Reuveni Z (1995). Development and postnatal regulation of adult myoblasts. Microsc Res Tech 30:366-380.

Yablonka-Reuveni Z (2011). The skeletal muscle satellite cell: still young and fascinating at 50. J Histochem Cytochem 59:1041-1059.

Yablonka-Reuveni Z, Day K, Vine A. Shefer G (2008). Defining the transcriptional signature of skeletal muscle stem cells. J Anim Sci 86:E207-E216.

Zhao Y, Samal E, Srivastava D (2005). Serum response factor regulates a muscle-specific microRNA that targets Hand2 during cardiogenesis. Nature 436:214-220.

Literature Cited 
Anderson C, Catoe H, Werner R (2006). MIR 206 regulates connexin43 expression during skeletal muscle development. Nucleic Acids Res 34:5863 5871.

Baar K (2010). Epigenetic control of skeletal muscle fibre type. Acta Physiol(Oxf) 199:477. 487.

Bentzinger CF, Wang YX, Rudnicki MA (2012). Building muscle: molecular regulation of myogenesis. Cold Spring Harb Perspect Biol4.

Bigot A, Duddy WJ, Ouandaogo ZG, Negroni E, Mariot V, Ghimbovschi S, Harmon B, Wielgosik A, Loiseau C, Devaney J, Dumonceaux J, Butler Browne G, Mouly V, Duguez S (2015). Age-Associated Methylation Suppresses SPRY1, Leading to a Failure of Re-quiescence and Loss of the Reserve Stem Cell Pool in Elderly Muscle. Cell Rep 13:1172-1182.

Boettger T, Wust S, Nolte H, Bram T (2014). The miR 206/133b cluster is dispensable for development, survival and regeneration of skeletal muscle. Skelet Muscle 4:23.

Braun T, Bober E, Winter B, Rosenthal N, Arnold HH (1990). Myf-6, a new member of the human gene family of myogenic determination factors: evidence for a gene cluster on ehromosome 12. EMBO J 9:821-831.

Carlson ME, Conboy MJ, Hsu M, Barchas L, Jeong J, Agrawal A, Mikels AJ, Agrawal S, Schaffer DV, Conboy IM (2009). Relative roles of TGF beta1 and Wnt in the systemic regulation and aging of satellite cell respenses. Aging Cell 8:676-689.

Chen JF, Mandel EM, Themsen JM, Wu Q, Callis TE, Hammend SM, Conlen FL, Wang DZ (2006). The role of microRNA 1 and mieroRNA 133 in skeletal musele proliferation and differentiation. Nat Genet 38:228 233 .

Collins CA, O1sen I, Zammit PS, Heslop L, Petrie A, Partridge TA, Morgan JE (2005). Stem cell function, self renewal, and behavioral heterogeneity of cells from the adult muscle satellite cell niche. Cell 122:289-301.

Collins CA, Zammit PS, Ruiz AP, Morgan JE, Partridge TA (2007). A population of myogenic stem cells that survives skeletal muscle aging. Stem Cells 25:885-894.

ComaiG, Tajbakhsh S (2014). Molecular and cellular regulation of skeletal myogenesis. Curr Top Dev Biol 110:1-73.

Conboy IM, Conboy MJ, Wagers AJ, Girma ER, Weissman IL, Rando TA (2005). Rejuvenation of aged progeniter cells by exposure to a young systemic envirenment. Nature $433: 760764$.

Crist CG, Montarras D, Pallafacehina G, Roeanceurt D, Cumano A, Conway SJ, Buekingham $\mathrm{A}$ (2009). Muscle stem cell behavior is modified by microRNA 27 regulation of Pax3 expression. Proc Natl Acad Sci U S A 106:13383-13387.

Davis RL, Weintraub H, Lassar AB (1987). Expression of a single transfected eDNA converts fibreblasts to myoblasts. Cell 51:987 1000 .

Deato MD, Marr MT, Sottero T, Inouye C, Hu P, Tjian R (2008). MyoD targets TAF3/TRF3 to activate myogenin transcription. Mol Cell 32:96-105.

Dey BK, Gagan J, Dutta A (2011). miR 206 and-486 induce myoblast differentiation by downregulating Pax7. Mol Cell Biol 31:203-214. 
Donaldson A, Natanek SA, Lewis A, Man WD, Hopkinsen NS, Polkey MI, Kemp PR (2013). Increased skeletal muscle-specific microRNA in the blood of patients with COPD. Thorax 68:1140-1149.

Edmondson DG, Olson EN (1989). A gene with homology to the mye similarity region of MyoD1 is expressed during myogenesis and is sufficient to activate the muscle differentiation program. Genes Dev 3:628-640.

Elia L, Contu R, Quintavalle M, Varrene F, ChimentiC, Russe MA, Cimino V, De ML, Frustaci A, Catalueei D, Condorelli G (2009). Reciprocal regulation of mieroRNA 1 and insulin-like growth factor-1 signal transduction cascade in cardiac and skeletal muscle in physiologieal and pathelogieal conditions. Cireulation 120:2377 2385.

Guenther MG, Levine SS, Boyer LA, Jaenisch R, Young RA (2007). A chromatin landmark and transcription initiation at most promoters in human cells. Cell 130:77-88.

Halevy O, Piestun Y, Allowh MZ, Rosser BW, Rinkevich Y, Reshef R, Rozenboim I, Wleklinski Lee M, Yablonka-Reuveni Z (2004). Pattern of Pax7 expression during myogenesis in the posthatch chicken establishes a model for satellite cell differentiation and renewal. Dev Byn 231:489 502

Hawke TJ, Garry DJ (2001). Myogenic satellite cells: physiology to molecular biology. J Appt Physiol (1985) 91:534-551.

Hutchesen DA, Zhae J, Merrell A, Haldar M, Karden G (2009). Embryonic and fetal limb myogenic cells are derived from developmentally distinct progenitors and have different requirements for beta-catenin. Genes Dev 23:997-1013.

Kassar Duchossoy L, Giaeone E, Gayratt Morel B, Jory A, Gomes D, Tajbakhsh S (2005). $\mathrm{Pax} 3 / \mathrm{Pax} 7$ mark a novel population of primitive myogenic cells during development. Genes Dev 19:1426-1431

Kunng S, Kuroda K, Le GF, Rudnicki MA (2007). Asymmetric self renewal and commitment of satellite stem cells in muscle. Cell 129:999 1010.

Lewis A, Riddoch-Contreras J, Natanek SA, Donaldson A, Man WD, Moxham J, Hopkinson NS, Polkey MI, Kemp PR (2012). Downregulation of the sermm response factor/miR 1 axis in the quadriceps of patients with COPD. Therax 67:26-34.

MeKinnell IW, Ishibashi J, Le GF, Punch VG, Addieks GC, Greenblatt JF, Dilworth FJ, RudnickiMA (2008). Pax7 activates myogenic genes by recruitment of a histene methyltransferase complex. Nat Cell Biol 10:77 84.

Moss FP, Leblond CP (1971). Satellite cells as the source of nuclei in muscles of growing rats. Anat Rec 170:421-435.

Naguibneva I, Ameyar-Zazoua M, Polesskaya A, Ait-Si-Ali S, Groisman R, Souidi M, Cuvellier S, Harel-Bellan A (2006). The microRNA miR-181 targets the homeobox protein Hox A11 during mammalian myoblast differentiation. Nat Cell Biol 8:278 284.

Nakajima N, Takahashi T, Kitamura R, Isodono K, Asada S, Ueyama T, Matsubara H, Oh H (2006). MieroRNA 1 facilitates skeletal myogenic differentiation witheut affecting osteoblastie and adipogenic differentiation. Biochem Biophys Res Commun 350:1006-1012. 
O'Rourke JR, Georges SA, Seay HR, Tapseott SJ, MeManus MT, Goldhamer DJ, Swanson MS, Harfe BD (2007). Essential role for Dicer during skeletal muscle development. Dev Biol 311:359-368.

Palacios D, Puri PL (2006). The epigenetic network regulating muscle development and regeneration. J Cell Physiol 207:1 11.

Parker MH, Seale P, Rudnicki MA (2003). Looking back to the embryo: defining transcriptional networks in adult myogenesis. Nat Rev Genet 4:497 507.

Perdiguero E, Sousa-Victor P, Ballestar E, Munoz-Canoves P (2009). Epigenetic regulation of myogenesis. Epigenetics 4:541-550.

Puig Vilanova E, Aguilo R, Rodriguez Fuster A, Martinez Llorens J, Gea J, Barreiro E (2014a). Epigenetic mechanisms in respiratory muscle dysfunction of patients with chronic obstructive pulmonary disease. PLoS One 9:e111514.

Puig Vilanova E, Ausin P, Martinez Llorens J, Gea J, Barreiro E (2014b). Do epigenetic events take place in the vastus lateralis of patients with mild chronic obstructive pulmonary disease? PLoS One 9:e102296.

Puig Vilanova E, Martinez Llorens J, Ausin P, Roea J, Gea J, BarreiroE (2015). Qurdriceps muscle weakness and atrophy are associated with a differentialepigenetic profile in advanced COPD. Clin Sei (Lond) 128:905-921.

Rao PK, Kumar RM, Farkhondeh M, Baskerville S, Lodish HF (2006). Myogenic factors that regulate expression of muscle-specific microRNAs. Proc Natl Acad SeiUS A 103:8721 8726.

Sacco A, Doyonnas R, Kraft P, Vitorovic S, Blau HM (2008). Self-renewal and expansion of single transplanted muscle stem cells. Nature 456:502-506.

Seale P, Sabourin LA, Girgis-Gabardo A, Mansouri A, Gruss P, Rudnicki MA (2000). Pax7 is required for the specification of myogenic satellite cells. Cell 102:777-786.

Shefer G, Van de Mark DP, Richardsen JB, Yablonka-Reuveni Z (2006). Satellite cell pool size does matter: defining the myogenic potency of aging skeletal muscle. Dev Biol 294:50-66.

Snow MH (1978). An auteradiographic study of satellite cell differentiation intoregenerating myotubes following transplantation of muscles in young rats. Cell Tissue Res 186:535-540.

Tajbakhsh S (2009). Skeletal muscle stem cells in developmental versus regenerative myogenesis. Jintern Med 266:372 389.

Wang H, Garzon R, Sun H, Ladner KJ, Singh R, Dahlman J, Cheng A, Hall BM, Qualman SJ, Chandler DS, Croce CM, Guttridge DC (2008). NF-kappaB-YY1-miR 29 regulatory circuitry in skeletal myogenesis and rhabdomyosarcoma. Cancer Cell 14:369_381.

Wang $\mathrm{L}$, Zhou $\mathrm{L}$, Jiang P, Lu L, Chen X, Lan H, Guttridge DC, Sun H, Wang H (2012). Loss of miR-29 in myoblasts contributes to dystrophic muscle pathogenesis. Mol Ther 20:1222-1233.

Weintraub H, Tapseott SJ, Davis RL, Thayer MJ, Adam MA, Lassar AB, Miller AD (1989). Activation of muscle-specific genes in pigment, nerve, fat, liver, and fibroblast cell lines by forced expression of MyoD. Proc Natl Acad Sci U S A 86:5434-5438.

Yablenka Reuveni Z (1995). Development and postnatal regulation of adult myeblasts. Mierese Res Tech 30:366-380 
Yablonka Reuveni Z (2011). The skeletal muscle satellite cell: still young and faseinating at 50. IHistochem Cytochem 59:1041 1059.

Yablonka-Reuveni Z, Day K, Vine A, Shefer G (2008). Defining the transeriptional signature of skeletal musele stem cells. J Anim Sei 86:E207-E216.

Zhao Y, Samal E, Srivastava D (2005). Serum response factor regulates a muscle-specific microRNA that targets Hand2 during cardiogenesis. Nature 436:214-220. 
Figure 1: Schematic representation of how local and systemic factors regulate Multiple 1.15 li

embryonic and postnatal muscle development. Biochemical epigenetic mechanisms alse contribute to regulate such processes. Muscle development determines muscle phenotype and function according to the type of muscle, which also have implications in muscle repair and regeneration following injury. 